Rok XVI (2021) | 1 (31) | S. 85-98

https://doi.org/10.12797/LV.16.2021.31.07

Marcin Kuźmicki ๑

Uniwersytet im. Adama Mickiewicza, Poznań

kuzmicki.mrcn@gmail.com

\title{
O PEWNEJ OSOBLIWOŚCI W WYDANIU KALISKICH ROT SĄDOWYCH, KTÓRA MOŻE STAĆ SIĘ PRZESTROGĄ DLA BADACZY ORAZ EDYTORÓW TEKSTÓW DAWNYCH
}

Słowa klucze: wielkopolskie roty sądowe, wydawanie tekstów staropolskich, rękopis, źródło, błędy Keywords: Greater Polish judicial oaths, editing Old Polish texts, manuscript, source, mistakes

Zapiska sądowa, o której mowa w tytule artykułu, znajduje się na karcie 67 recto $^{1}$ księgi ziemskiej kaliskiej i doczekała się trzech wydań. Pierwsze ukazało się w roku 1974. Było to wydanie przygotowane przez Henryka Kowalewicza oraz Władysława Kuraszkiewicza (WRS). Kolejnym wydaniem, w którym pojawia się owa zapiska, jest Ksiega ziemska kaliska 1400-1409, opracowana przez Tomasza Jurka, która ukazała się w 1991 roku. Ostatni raz zapiska ta została opracowana w ramach programu badawczego eROThA ${ }^{2}$. Czas, który dzieli owe wydania (pierwsze od ostatniego), to niemalże pół wieku. To również czas, w którym dokonał się przełom technologiczny, jeśli chodzi o przygotowywanie rękopisu do edycji.

Osobliwość edytorska, która ma się stać tylko pewnym pretekstem, by ukazać szerszy problem edytorstwa tekstów średniowiecznych, to fakt dwukrotnego opra-

1 Konkordancję foliacji dawnej i obecnej znajdzie czytelnik na stronach XII-XVII w wydaniu KZKJur. Dodatkowo na stronie V tegoż wydania można znaleźć informacje dotyczące zmian, których dokonywano w interesującej nas księdze kaliskiej pierwszej, nim ostatecznie w 1989 roku ustalono jej kształt, który znany jest nam do dziś.

2 eROThA: https://rotha.ehum.psnc.pl/. 
cowania jednej i tej samej zapiski sądowej w tym samym wydaniu. Raz opatrzona została ona numerem 90, drugi raz - 237. Obie znalazły się w wydaniu Wielkopolskich rot sądowych... opracowanym przez H. Kowalewicza i W. Kuraszkiewicza. Jest to pomyłka, którą można sobie wytłumaczyć, zwłaszcza mając na względzie ogrom materiału, z którym musieli się obaj wydawcy zmierzyć, oraz wspominane różnice technologiczne. Dziś udogodnienia technologiczne pozwalają nam unikać takich pomyłek, lecz niemalże pół wieku temu wspomniani wydawcy nie dysponowali takimi możliwościami (praca na fiszkach czy maszynopisie w porównaniu z pracą na plikach w pełni przeszukiwalnych i dających się edytować na bieżąco, w dodatku z możliwością seryjnego wprowadzania zmian). Osobliwość dotyczy jednak czegoś więcej niż powtórzenie tej samej zapiski sądowej dwukrotnie w wydaniu. Aby to dostrzec, trzeba przyjrzeć się fragmentowi karty rękopisu, na którym ta zapiska została odnotowana przez średniowiecznego skrybę. A zatem karta 67 recto:

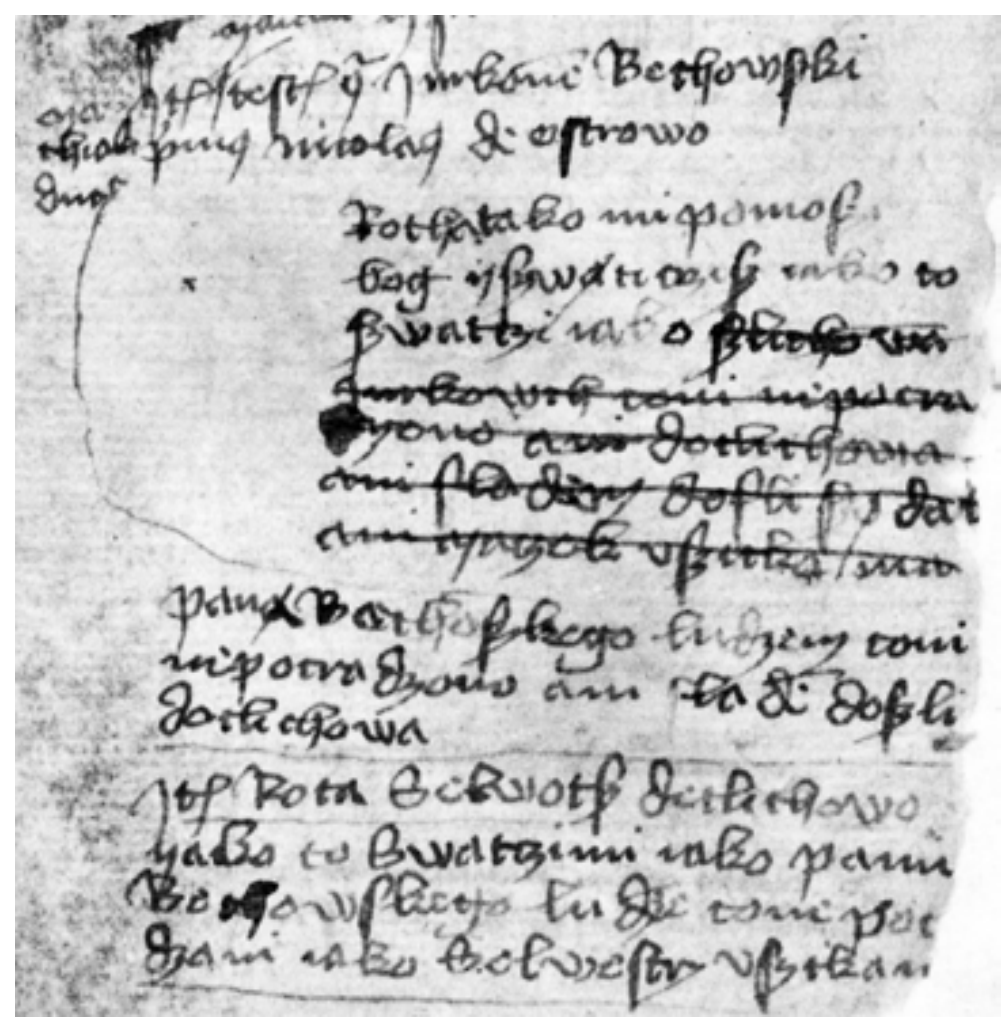

Fragment ten przedstawia dosyć typowy obraz średniowiecznych zapisek sądowych, w których występują liczne skreślenia, pojawiają się glosy oraz abrewiacje. Co więcej, nakłada się na ten obraz dodatkowy czynnik, jakim jest uszkodzenie rękopisu powstałe na przestrzeni wieków (np. uszkodzenia mechaniczne, zaplamienia, 
wytarcia atramentu). Wszelkie tego typu informacje powinny oczywiście zostać zawarte w naukowym wydaniu, choć między poszczególnymi wydaniami mogą się pojawiać różnice wynikające z przyjętych zasad wydawania ${ }^{3}$.

Poniżej prezentuję przykłady opracowania interesującego nas fragmentu z karty 67 recto przez poszczególnych badaczy:

- opracowanie H. Kowalewicza i W. Kuraszkiewicza:

90. (39) - Item \{Mathias dueit\} testes contra Jurkonem Bechowszki: primus Nicolaus de Ostrowo. - Rotha:

tako mi pomolzi | bog yfzwąti Tako mi pomoży Bog i swięty ezilz iako to | fzwatezi iako Ifzbe- krzyẑ, jako to swiadezy, jako [z Be-

chowa | Jurkowich coni nepocra| dzyono coni doclichowa | ani fladem dolli Groda | ani Maczek vizitka ma] | paną Becholzkego ludzem coni nepocradzono ani llade $^{m}$ dofzli | doclichowa chowa Jurkowych koni nie peiksidziono [koni] do Klichowa, ani sladem doszli sq̨a, ani Macick użytka ma] pana Becho $\langle w\rangle$ skiego ludziem koni nie pokradziono, ani sladem doszli do Klichowa.

237. (I 39 r. 1403) - Item Mathins \{ducit\} testes contra Jurkonem Bechowszki: primus Nicolaus de Ostrowo. - Rotha:

tako mi pomofzi | bog ÿlzwąti crzilz iako to | fzwatezi iako [fzbechowa | Jurkowich coni nepocra|dzyono coni doclichowa | ani Mladem dolli [zeda | ani Maczek vfzitka ma ] ] paną Bechofzkego ludzem coni nepocradzono ani fladem dofzli | doclichowa

Item rota Selwotsz de Clichoro: yako to Swatezimi iako panu | Bechowfkego ludzem cone pocr $\langle a\rangle$ I dzoni iako Selweftrz vfztka $m\langle a \dot{ }\rangle$
Tako mi pomoźy Bog i 6więty krzyż, jako to swiadeze, jako [z Beehowa Jurkowyeh koni nie pokra. dxiono [koni] do Klichowa, ani sladem doszli sąda, ani Maciek nzytka mal pana Becho $\langle\mathbf{w}\rangle$ skiego ludziem koni nie pokradziono ani sladem doszli do Klichowa.

$--$

Jako to swiadczymy, jako pana Bechowskiego ludziem konie pokr $\langle a\rangle$ dziony jako Selwestrz uż $\langle\mathbf{y}\rangle$ tka $\mathrm{m}\langle\mathbf{a}\rangle$.

3 Zasady wydawania wpływają na sposób prezentowania rękopisu, czyli na to, co finalnie stanie się tekstem, z którym obcuje jego odbiorca (por. Kuźmicki 2015, 2017). 
- fragment za wydaniem T. Jurka:

1104. Item Jassko de +Mlino- Wlina cum Stanislao de Crokowo habent limitacionem post diem Fsancti- Martini infra duas scptimanas.

1105. Item \{Mathias ducit\} testes contra Jurkonem Bechows/ki: primus Nicolaus de Ostrowo.

Rotha. Tako mi pomoszi Bog y szwati Crzisz, iako to szwatczi, iako tsz Bcchowa Jurkowch ${ }^{1}$ coni ne pocradzyono aniz do Clichowa, ani sladem dosli szoda, ani Maczck vszitka matpana Bcchoszkego ludzem coni ne pocradzono, ani sladem doszli do Clichowa.

Roty 90 (= Roty 237): Jurkowich, 2coni.

- fragmenty pochodzące z Elektronicznego Repozytorium Rot Wielkopolskich (eROThA Ka.9o, Ka.237):

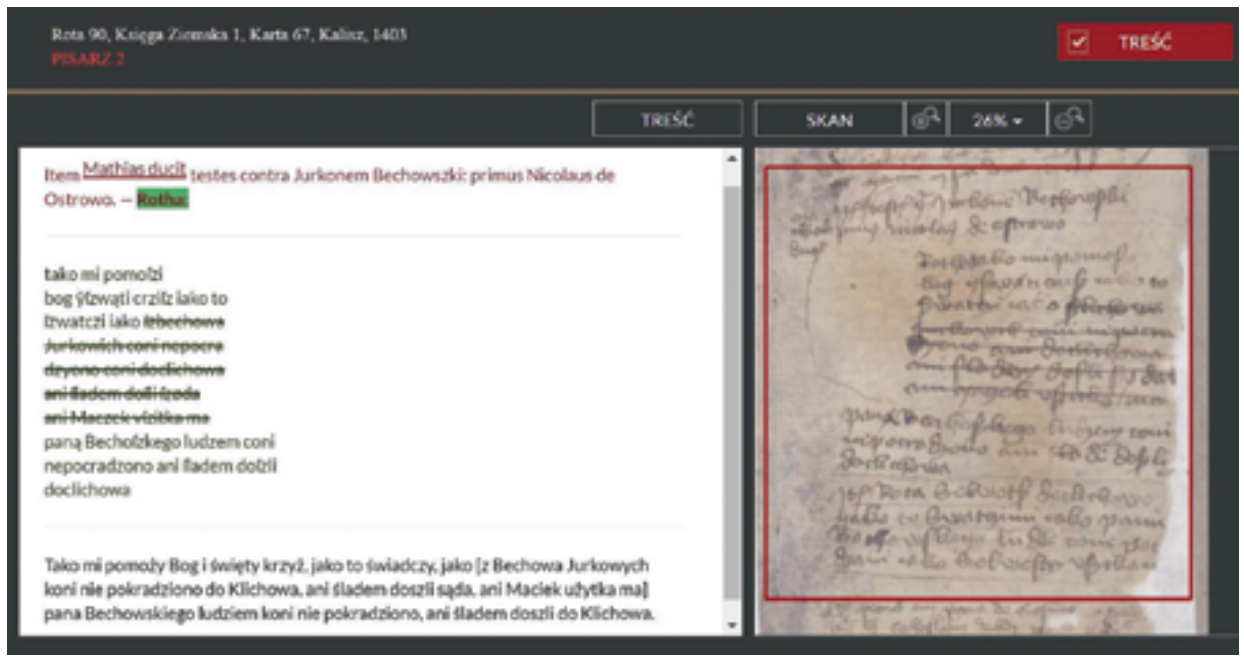



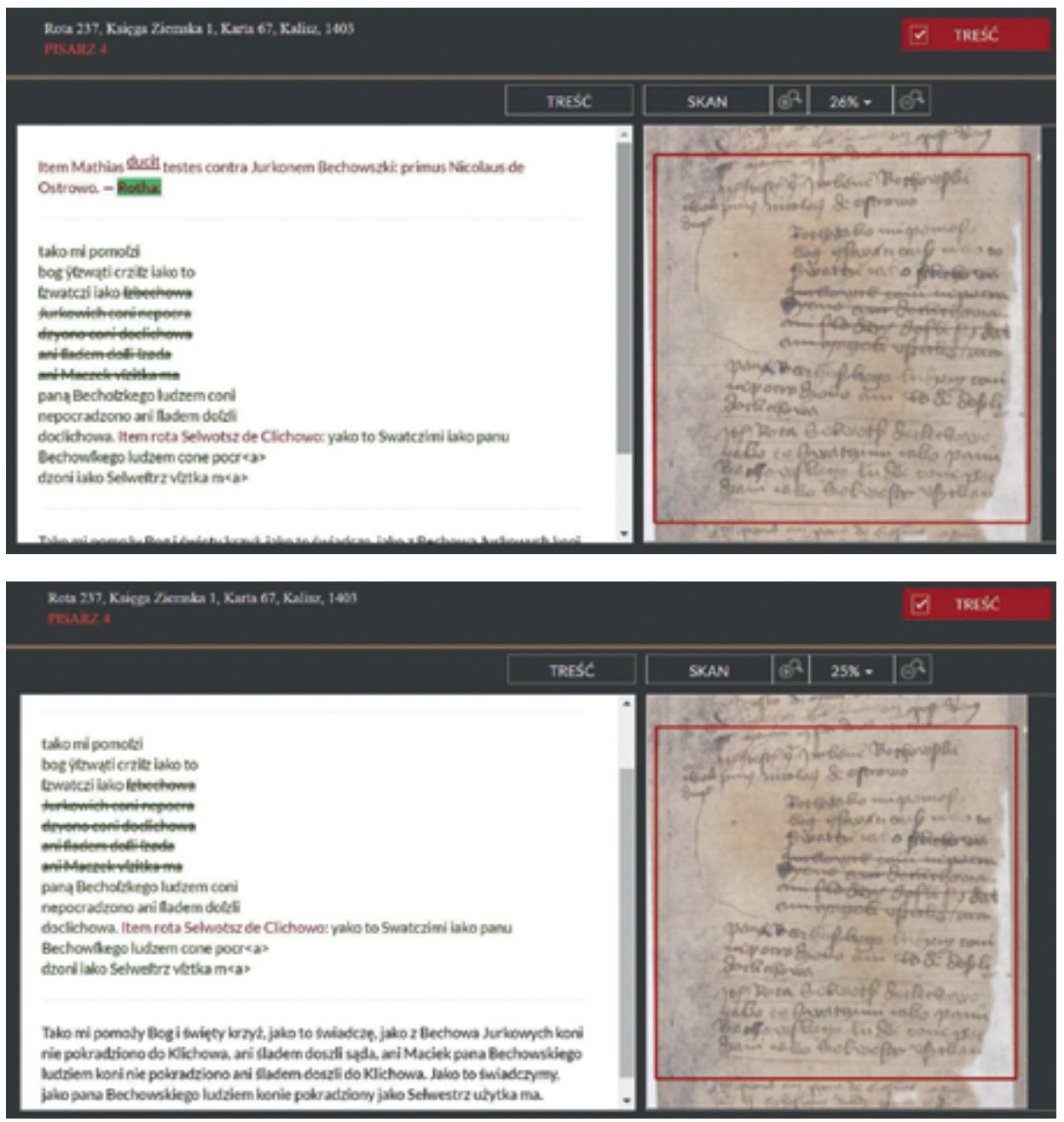

Tytułową osobliwość sprowadzić można do trzech zagadnień. Po pierwsze, jest to wydanie tego samego fragmentu rękopisu w odmienny (!) sposób. Po drugie, rozpoznano i przypisano do tej samej zapiski dwie odmienne ręce pisarskie. Po trzecie wreszcie, dwukrotnie ustalono inną granicę zapiski sadowej. Każda z tych kwestii rzutuje na przyjęte wcześniej zasady wydawania tekstu, każe zadać sobie pytanie o ich spójność, niezmienność, a także o pewną konsekwencję w podejściu do wydawanego rękopisu.

Uwagi zacząć wypada od kwestii drugiej, natury podstawowej - paleograficznej. Okazuje się bowiem, że rozpoznawanie rąk pisarskich jest trudną sztuką, nierzadko nawet bardzo wprawne oko badacza może dać się zwieść na manowce. Dużo zależy od tego, w jaki sposób zestawimy materiał, który ma zostać poddany analizie. Spo- 


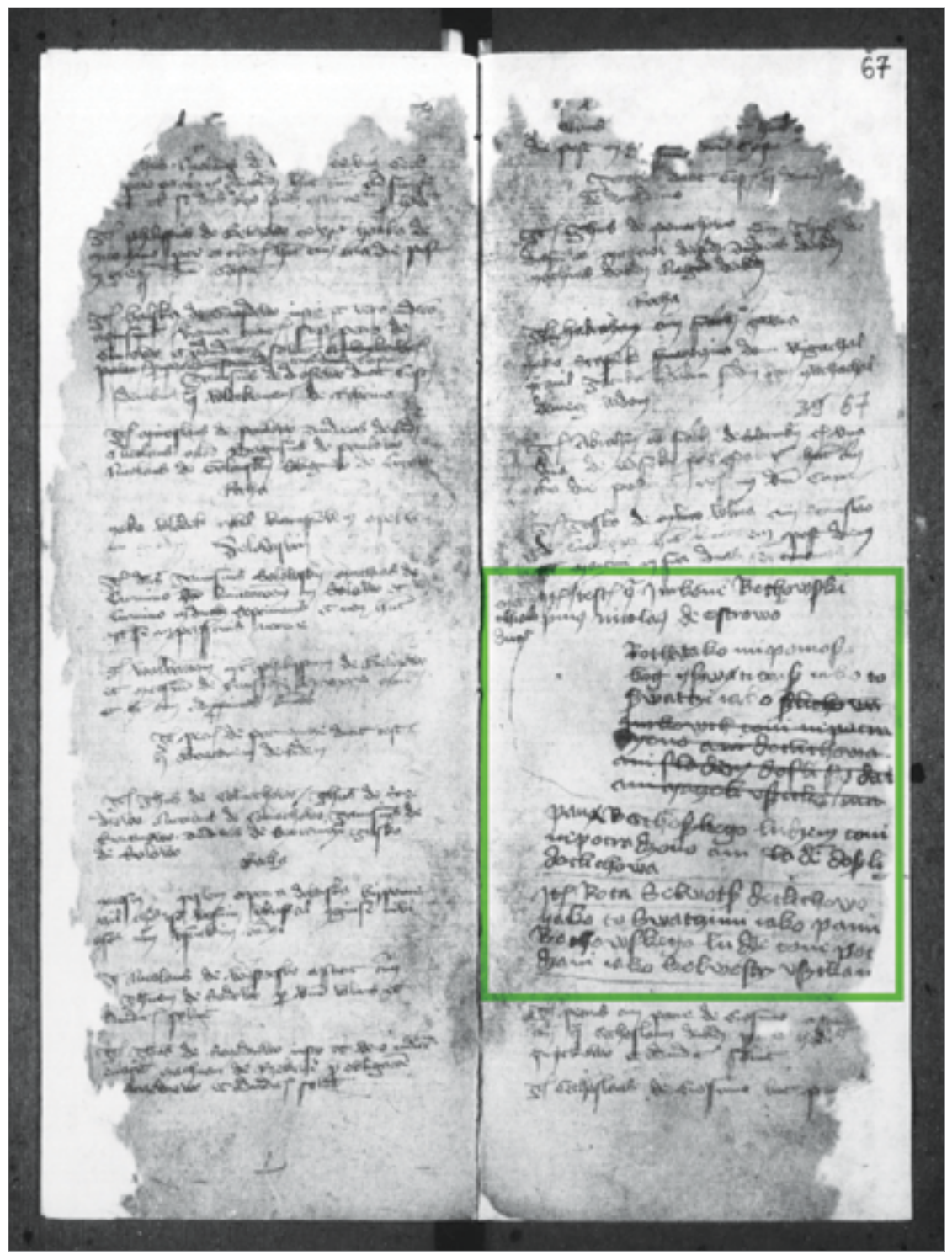

glądając na kartę 67 recto (dawniej 39r), wyraźnie da się zauważyć odmienny dukt ręki, który wedle H. Kowalewicza charakteryzuje pisarza 4 (dukt zakreślony na fotografii zieloną ramką).

We wstępie do wydania Wielkopolskich rot sądowych... tak została scharakteryzowana ręka pisarska 4:

Pisarz 4 (rota nr 237 z 1403 r.). Jedyna jego polska zapiska na k. 39 księgi I została wniesiona ręką nie tak wprawną jak ręce pozostałych pisarzy. Szereg liter ma wy- 
gląd odmienny od liter w zapiskach innych rąk, ale najbardziej charakterystyczne jest $w$ bez pętli, pisane trzema pociągnięciami pióra (WRS: 16 ).

Charakterystykę tę przyjmuje również T. Jurek w swym wydaniu (KZKJur: IX): „Pisarz 7 (w Rotach zwany pisarzem 4) wpisał dwie zapiski na k. 67r (nr 1105-1106)”. Różnice w paginacji zostały już objaśnione, natomiast rozbieżności co do liczby zapisek, które sporządził ów pisarz, będą jeszcze poruszane.

Ta sama zapiska opatrzona zastała również numerem $90 \mathrm{w}$ wydaniu z 1974 roku, eo ipso uznano ją za dzieło pisarza 2:

Pisarz 2 (227 rot, nr 3-229 z lat 1401-1407). Chociaż jego zapiski w księdze I pochodzą z okresu kilku lat, to jednak charakterystyczne pismo nie ulega większym zmianom. Dukt przypłaszczony; swoiście załamywana litera J, górna część laski załamana w prawo. Prawie wszystkie litery wykazują graficzne różnice między tą ręką a rękoma innych pisarzy, co pozwala na wyraźne wyodrębnienie tekstów wniesionych przez pisarza 2 (WRS: 10 ).

Wraz z innymi zapiskami tego pisarza zostały omówione stosowane przez niego poszczególne formy graficzne, gramatyczne oraz leksykalne (np.: nie odróżnia głosek $i$ - $y$, pisze najczęściej $i$ - crzisz 90; samogłoski nosowe normalnie oznacza przez $\varnothing$ (przekreślone o) we wszystkich pozycjach w wyrazie - szøda 90, wyjątkowo trafiła się inna pisownia szwąti 90; z odmiany rzeczowników wymienić należy wahanie końcówek w miejscowniku w liczbie mnogiej - ludzem 9o; imiona osób w tekście łacińskim zwykle mają pełną postać, natomiast w tekście polskim są na ogół skrócone - Mathias - Maczek 9o) $)^{4}$.

Zapewne duże wątpliwości budzi analiza paleograficzna, w wyniku której tej samej zapisce sądowej przypisane zostały dwie różne ręce pisarskie. Jednakże gdy spojrzy się na tę rozbieżność w kontekście niemalże dwustu trzydziestu zapisek pisarza drugiego, dodatkowo zapisanych na przestrzeni siedmiu lat, oraz uwzględni zmienność duktu pisma w zależności od wieku i praktyki pisarskiej, łatwiej można zrozumieć decyzję wydawców, by zapiskę nr 90 zinterpretować również jako dzieło pisarza drugiego, choć w innym miejscu wydania widzą w tej zapisce zupełnie odmienną rękę pisarską.

Rozbieżności pomiędzy jedną a drugą wersją wydanej zapiski ujawniają się również na poziomie wyznaczenia granicy zapiski sądowej (Kuźmicki 2015). Zapiska opatrzona numerem 90 kończy się na słowach: doszli do Klichowa, druga zaś, oznaczona numerem 237, po tych słowach ma dopisaną jeszcze jedną rotę, która znajduje się pod tym samym numerem i rozpoczyna od słów Item rota Selwotsz de Clichowo.

4 Wszystkie przykłady pochodzą z opisu tzw. ręki pisarskiej drugiej zamieszczonego we wstępie do WRS: $10-16$. 


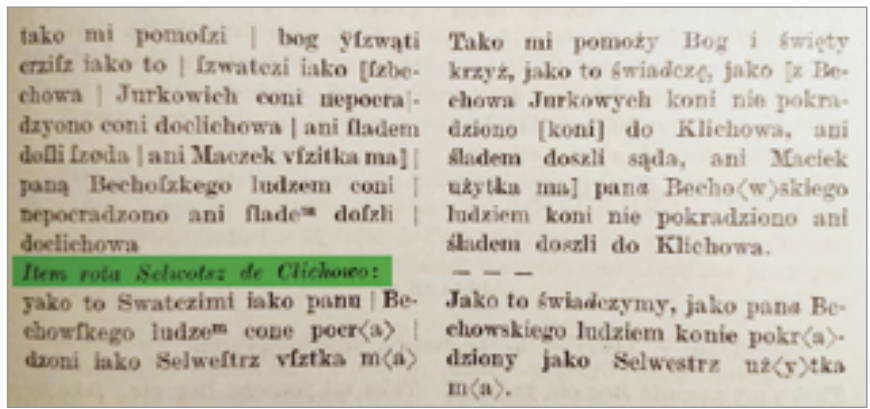

W wydaniu T. Jurka zapiska rozpoczynająca się od tych słów została wydzielona i ma już osobny numer (1106):

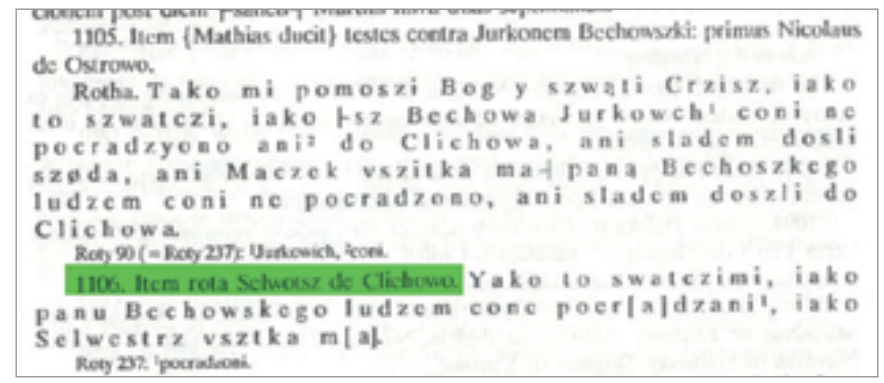

Gdyby zatem wydawcy Wielkopolskich rot sadowych... poprzestali na zapisce opatrzonej numerem 9o, czyli gdyby omyłkowo nie powtórzyli w wydaniu tej samej zapiski, czytelnik najprawdopodobniej w ogóle nie dowiedziałby się o dalszym fragmencie tekstu rozpoczynającym się od słów Item rota Selwotsz de Clichowo.

Pozostaje do omówienia wreszcie kwestia najistotniejsza, mianowicie odnosząca się do samego odczytania/interpretacji tekstu ${ }^{5}$.

Już w łacińskiej części wstępnej ujawnia się pierwsza różnica: Item \{Mathias ducit\} testes... w zapisce nr 90, tak natomiast w powtórzonej nr 237: Item Mathias \{ducit\} testes... Różnica sprowadza się zatem do odmiennie umieszczonego nawiasu. Konsekwencją tej decyzji jest całkowicie odmienne postrzeganie redakcji średniowiecznego tekstu, gdyż ujęcie elementów w nawias wskazuje, że stanowią one glosę

5 O specyfice tekstów średniowiecznych i problemach związanych z ich odczytaniem, które staje się jednocześnie ich interpretacją, z określeniem dokładnego obiektu badań i specyficznych narzędzi opisu napisano już bardzo wiele. Dość przypomnieć klasyczną już książkę Wacława Twardzika (1997). O specyfice tekstu staropolskiego i problemach z jego badaniem pisał wielokrotnie Tomasz Mika (2009, 2012, 2015). Na interpretacyjny charakter transliteracji wskazują: Mika 2009; Trawińska 2011, 2014; Kuźmicki 2013; kwestię interpretacyjnego charakteru interpunkcji i w ogóle delimitacji tekstu, także w kontekście interpretacji składni, poruszali chociażby: Mika 2009; Stramczewska 2014. 
zapisaną gdzieś poza tekstem głównym. Wedle jednej wersji glosowany jest wyłącznie czasownik ducit, w drugiej glosa okazuje się bardziej rozbudowana: Mathias ducit. Na skanie rękopisu wyraźnie widać, że Ma|thias $\mid d u c^{\text {it }}$ jest glosą marginalną, zatem w nawias powinny być wzięte oba słowa, dokładnie tak, jak uczynili to wydawcy w zapisce nr 9o. W wydaniu T. Jurka glosa oznaczona została poprawnie.

Możliwość konfrontowania wydania z rękopisem, a także z innymi wydaniami, pozwala dostrzec rzeczy, które umknęly uwadze wcześniejszych wydawców. Odmienne odczytania dwóch miejsc $\mathrm{z}$ omawianej zapiski zaproponował $\mathrm{w}$ swym wydaniu T. Jurek. Słusznie wykazał on, że w skreślonym fragmencie poprzedni wydawcy pomylili się, i to dwukrotnie: pierwszy raz, gdy w transliteracji uzupełnili zapis Jurkowch (tak w rękopisie) o brakujące $i$ - Jurkowich, nie zaznaczając tego faktu w wydaniu żadnym znakiem edytorskim, drugim razem błąd był nieco poważniejszy (wytłumaczalny, paleograficznie dający się wyjaśnić, choć ponownie okazało się, że odczytanie T. Jurka ma solidniejsze podstawy), ponieważ wprowadził do treści zapiski rzeczownik (coni, czyt. „koni”), który później w części transkrypcyjnej wydawcy - konsekwentnie respektując własne odczytanie - byli zmuszeni umieścić w nawiasie prostokątnym, uznając wyraz za zbędny, niepotrzebnie powtórzony przez pisarza (przykład oznaczony dwiema strzałkami na poniższym zdjęciu). Tym razem jednak nie pisarz się pomylił, lecz wydawcy Wielkopolskich rot sadowych... Gdy wbrew temu, co proponowali H. Kowalewicz i W. Kuraszkiewicz, w pierwszej literze zobaczymy nie $c$, lecz część litery $a$, sprawa stanie się jasna i zrozumiała, bo $\mathrm{z}$ rzeczownika $\mathrm{w}$ domniemanym genetiwie pluralis zapisanego coni otrzymamy spójnik wyłączający ani, doskonale wpisujący się w treść zapiski: Jurkowych koni nie pokradziono ani do Klichowa, ani śladem doszli sąda, ani [...].

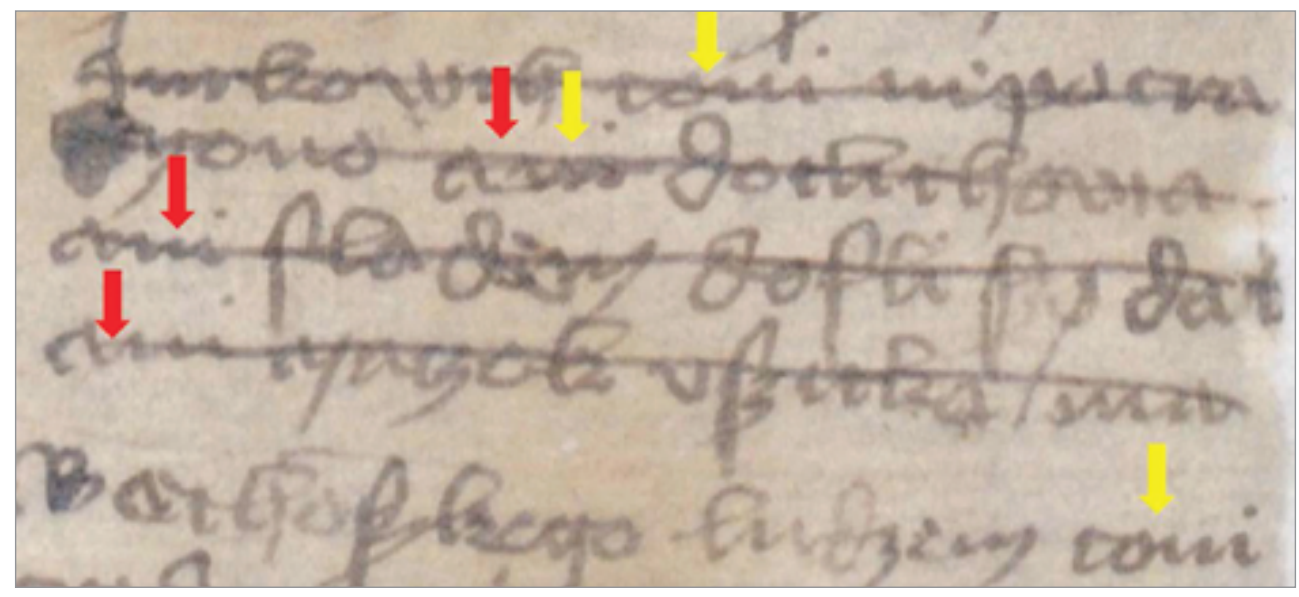

Na zdjęciu żółtymi strzałkami zaznaczono wyraz coni, czerwonymi zaś spójnik ani. Dwie strzałki znajdują się przy wyrazie o odmiennych interpretacjach, odczytaniach paleograficznych. 
Ostatnie różnice dostrzeżone $\mathrm{w}$ obu wersjach wydania WRS uwidaczniają się w transkrypcji tekstu. W zapisce 90 przysięga brzmi:

Tako mi pomoży Bog i święty krzyż, jako to świadczy.

W zapisce 237 transkrypcja wygląda już następująco:

Tako mi pomoży Bog i święty krzyż, jako to świadczę.

Trzeba raz jeszcze przypomnieć, że jest to ta sama zapiska, lecz umieszczona $\mathrm{w}$ wydaniu dwukrotnie przez pomyłkę. W pierwszym przykładzie wydawcy pozostawiają końcówkę 3. os. sg. - $y$. Drugim razem zmieniają ją na -ę, czyli końcówkę 1. os. sg., co zaznaczają kursywą, dając tym samym czytelnikowi do zrozumienia, że ma do czynienia z błędem w rękopisie. Decyzja o zmianie końcówki z 3. os. sg. na 1. os. sg. była podyktowana zapewne treścią zapiski, tym, że po wskaźniku zespolenia tako następuje zaimek 1. os. sg. w datiwie, zatem i po jako powinna się znaleźć forma 1.os. sg. Sens zapiski przesądził o decyzji wydawców i o wprowadzonej korekcie. Dlaczego nie wprowadzono podobnej korekty w zapisce nr 9o, tego nie sposób już ustalić, pozostawiono odczytanie wierne zapisowi. Brak ingerencji wydawców może jednak wskazywać albo na przeoczenie tego problemu, albo na refleksję dotyczącą powstawania tego rodzaju tekstów. Były to teksty kopiowane, wpisywane do ksiąg zapewne ze sporządzonych wcześniej przez pisarza sądowego notatek. Dlatego też pojawienie się formy 3. os. sg. nie musi być błędem pisarskim, może być celowym zabiegiem - pisarz sądowy zastosował tę formę, opisując zdarzenie nie z punktu widzenia uczestnika procesu sądowego, a z perspektywy osoby sporządzającej notatkę, która dopiero w dalszej kolejności zostanie przeredagowana, by zapisać ową rotę w księdze. Wówczas to, wraz ze zmianą perspektywy nadawczo-odbiorczej, pisarz może zmieniać formy gramatyczne. Pierwotnie rota redagowana była w takim kształcie, w jakim miała być wypowiedziana przez przysięgającego. Wówczas konieczna była forma 1. os. sg. lub pl., by nie narazić się na tzw. potyczel, czyli niesprawność przysięgi z powodu niesprawności w wysłowieniu się, co prowadziło do upadku w dowodzie (Bardach 1965: 550).

Ostatnia różnica dotyczy transkrypcji zapisu: paną (tak w rękopisie). W obu zapiskach ostatecznie znajduje się w transkrypcji forma pana, lecz w zapisce nr 90 ostatnie - $a$ nie jest oznaczone kursywą tak, jak to uczynili już wydawcy w przykładzie 237 (pana), gdzie kursywa ponownie wskazuje na pomyłkę pisarską. W tej samej zapisce, ale umieszczonej w dalszej części wydania księgi, wydawcy są skłonni widzieć pomyłki pisarskie częściej niż za pierwszym razem. W świetle grafii średniowiecznej, a dokładnie wielofunkcyjności znaków $a$ oraz a (zarówno jedna jak i druga litera mogły być stosowane na oddanie samogłoski ustnej $a$ oraz nosowej $a$ ), niemożliwa staje się jednoznaczna interpretacja decyzji edytorów w kwestii stosowania kursywy lub jej braku w formie pana. 
Wydanie T. Jurka nic nie wnosi do kwestii transkrypcji, gdyż zapiski polskie są w nim oddane za pomocą transliteracji, jednakże daje się odnaleźć pewne elementy przynależące do porządku transkrypcyjnego (np.: wpisywanie od wielkiej litery nazw własnych - także nomina sacra mają zapis wielką literą, pojawianie się współczesnej interpunkcji oraz skonwencjonalizowanej pisowni łącznej i rozdzielnej, brak oznaczania abrewiacji). Widać zatem, że rozwiązania przyjęte przez wydawcę są oparte o zasady stosowane przy wydawaniu tekstów łacińskich. Owa dwujęzyczność tekstów w całej swej mocy ujawnia problem stosowania dwóch porządków wydawania tekstów - jednego dla tekstów średniowiecznych polskich, drugiego dla źródeł łacińskich (Kuźmicki 2013).

Nie są to światy tak odległe, by nie można było uspójnić owych zasad, zwłaszcza $\mathrm{w}$ czasach, w których badania interdyscyplinarne są dobrem naddanym w pracach naukowych. Nadmierna konwencjonalizacja zapisu doprowadza do sytuacji, w których niemożliwe staje się badanie określonych obszarów i tekstu, i języka, pewne pytania nigdy nie zostaną postawione, a w najlepszym wypadku badacz jest zmuszony do sięgania po rękopis i rozczytywania go na nowo. Błędy pisarskie (często w ogóle bez informacji na temat ich występowania), użycie wielkich liter w rozmaitych funkcjach (nie tylko polszczyzna, także język łaciński), pisownia łączna i rozdzielna (wpływa czasami na określenie funkcji pewnych wyrazów), brak oznaczania abrewiacji (w przypadku polszczyzny adaptacja pewnych wzorców łacińskich do zapisywania języka, dla którego alfabet łaciński wciąż był w średniowieczu - a i jeszcze później - obszarem wypracowywania wzorców pisownianych) to jedynie niektóre ze zjawisk, po jakich ślady w edycjach znikają. Procesy normalizacyjne często były znacznie późniejsze niż teksty, do których staramy się je zastosować. W pewnych wypadkach stan badań/wiedzy na temat tych zjawisk uniemożliwia zastosowanie odpowiednich rozwiązań, dlatego uciekamy się do uwspółcześnienia tekstu w danym zakresie (np. samogłoski nosowe).

We współczesnej polszczyźnie ustaliła się norma pisowni rozłącznej partykuły przeczącej z czasownikami, jednakże w języku czeskim ta zasada nie obowiązuje stosuje się pisownię łączną. W średniowiecznych tekstach polskich podobnie jak w dzisiejszych czeskich zapisywano łącznie ową partykułę, co da się zaobserwować tylko wówczas, gdy nie będziemy uwspółcześniać pisowni w tym zakresie, czego się zazwyczaj nie praktykuje. Zatem badanie tego zagadnienia będzie możliwe jedynie w oparciu o rękopisy.

Wydawanie tekstu jest nie tylko procedurą badawczą, ale jest również pewnym procesem. $\mathrm{O}$ ile procedura, czyli unormowany zasadami sposób postępowania, wymaga stosowania pewnych niezmiennych, wcześniej ustalonych kryteriów, tak procesualność czynności, jaką jest wydawanie, sprawia, że czasem zmienia się nasze spojrzenie na wydawany tekst, co nie zawsze jest możliwe do uchwycenia, a nawet nie zawsze jesteśmy tego świadomi (przynajmniej nie od razu). Przy współczesnej technologii (w erze komputerów, skanerów, OCR-ów, wirtualnych chmur) znacz- 
nie łatwiej być konsekwentnym, a przynajmniej ma się większą kontrolę nad wydawanym tekstem, który jest przeszukiwalny obecnie niemal pod każdym kątem. Na uwadze wszakże trzeba mieć fakt, że nie zawsze tak było.

W kontekście powyższych uwag trzeba jednak powrócić do opublikowanych w ramach projektu eROThA zapisek sądowych. Niewątpliwą zaletą Elektronicznego Repozytorium Rot Wielkopolskich jest zamieszczenie skanu rękopisu, który można zestawić z tekstem wydania. W zakładce „O projekcie”, a następnie w kolejnej odsłonie, „Od wydania do repozytorium cyfrowego”, możemy przeczytać, że

podstawą wyboru i odczytania tekstów zawartych w księgach ziemskich jest monumentalne wydanie przygotowane przez historyka i paleografa Henryka Kowalewicza oraz językoznawcę Władysława Kuraszkiewicza (1959-81). Dziś publikacja ta wymaga uzupełnień, nowych interpretacji, a może nawet rewizji (zob. Uwagi paleograficzne autorstwa Olgi Makarovej), a jednak jako baza wielu przedsięwzięć badawczych oraz kanonicznych źródeł wiedzy o języku staropolskim i łacinie w polskim średniowieczu, zasługuje także na otwartą i elastyczną formę publikacji cyfrowej. Dlatego też transkrybowane przez Redaktorów teksty łacińskie oraz transliterowane przysięgi polskie prezentowane są $\mathrm{w}$ nowoczesnym formacie kompatybilnym ze standardem TEI (eROThA).

Zasadniczo tekst zapisek sądowych został przepisany w niezmienionej formie. Wprowadzono różne kolory fontu, by zaznaczyć dwa porządki: transkrypcyjny i transliteracyjny, górną frakcją zaznaczono abrewiacje, zrezygnowano ze specjalnych znaków edytorskich, by zaznaczyć skreślenia w rękopisie, w zamian za to przekreśla się całe analogiczne fragmenty w wydaniu. Niestety to ostatnie rozwiązanie może imituje odpowiednie miejsce z rękopisu, lecz również zaciera czytelność samego tekstu. Nie to jest jednakże największym mankamentem i niedociągnięciem, z którym musi zmierzyć się czytelnik eROThA. Nieważne, które wydanie staje się podstawą do publikacji poszczególnych zapisek sądowych, zawsze trzeba mieć na uwadze, że nauka się rozwija, wiedza ma charakter kumulatywny, że wydanie Wielkopolskich rot sq̨dowych... H. Kowalewicza i W. Kuraszkiewicza, pomimo niezaprzeczalnego monumentalnego charakteru, też się starzeje i traci na aktualności, co $\mathrm{w}$ wielu miejscach słusznie pokazał w swym wydaniu T. Jurek. W wykazie literatury na stronie Elektronicznego Repozytorium Rot Wielkopolskich widnieje wydanie opracowane przez T. Jurka, co każe założyć, że nowsze ustalenia powinny znaleźć jakiekolwiek odzwierciedlenie w publikacji eROThA, tymczasem wszystkie błędy i pomyłki H. Kowalewicza i W. Kuraszkiewicza zostały bezrefleksyjnie powtórzone. Ów brak akrybii we wspomnianej publikacji nie tylko nie budzi zaufania badacza-edytora, lecz również odbiera czytelnikowi możliwość zapoznania się z summą wiedzy na temat wydanych rot sądowych. 


\section{Źródła}

eROThA: eROThA (Elektroniczne Repozytorium Rot Wielkopolskich), [on-line:] https:// rotha.ehum.psnc.pl/.

KZKJur: Księga ziemska kaliska 1400-1409, wyd. T. Jurek, Poznań 1991.

WRS: Wielkopolskie roty sadowe XIV-XV wieku, t. IV: Roty kaliskie, zebr. i oprac. H. Kowalewicz, W. Kuraszkiewicz, Wrocław - Warszawa - Kraków - Gdańsk 1974.

\section{Literatura}

Bardach J., 1965, Historia państwa i prawa Polski, t. 1: Do połowy XV wieku, wyd. 3 popr. i uzup., Warszawa.

Kuźміскі M., 2013, Wspótistnienie języków w rotach przysiag sądowych, „Slavia Occidentalis. Linguistica" $70 / 1$, s. 75-85.

Kuźmicкi M., 2015, Wydanie Wielkopolskich rot sądowych $w$ świetle najnowszych ustaleń badawczych, „LingVaria” nr 2 (20), s. 205-219, [on-line:] https://doi.org/10.12797/ LV.10.2015.20.16.

Kuźміскі M., 2017, Problemy edytorstwa staropolskiego na przykładzie dawnych zapisek sadowych, [w:] K. Borowiec, D. Masłej, T. Mika, D. Rojszczak-Robińska (red.), Jak wydawać teksty dawne, „Staropolskie Spotkania Językoznawcze”, t. 2, Poznań, s. 369-39o.

MıкA T., 2009, Interpunkcja Kazań świętokrzyskich a ich składnia i styl, [w:] P. Stępień (red.), Kazania świętokrzyskie. Nowa edycja. Nowe propozycje badawcze, Warszawa, s. 59-80.

Miка T., 2012, Genetyczna wielowarstwowość i złożoność tekstów staropolskich a ich badania historycznojęzykowe. Rekonesans, „Biuletyn Polskiego Towarzystwa Językoznawczego” LXVIII, s. 131-145.

Mika T., 2015, Tekst staropolski jako odmienny obiekt badań? W poszukiwaniu narzędzi opisu, „LingVaria” nr 2 (20), s. 235-250, [on-line:] https://doi.org/10.12797/LV.10.2015.20.18.

StramczewsKa O., 2014, Interpunkcja transkrypcji. Znad „Rozmyślania przemyskiego”, Lublin.

Trawińska M., 2011, Jeszcze raz o szestroku. $Z$ badań nad rękopisem rot sądowych, [w:] B. Dunaj, M. Rak (red.), Badania historycznojezzykowe. Stan, metodologia, perspektywy, „Biblioteka LingVariów”, t. 14, Kraków, s. 175-183.

Trawińska M., 2014, Rękopis najstarszej poznańskiej księgi ziemskiej (1386-140o), Warszawa - Poznań.

Twardzik W., 1997, O uważniejszym aniżeli dotychmiast tekstu staropolskiego czytaniu i jakie z niego pożytki plyną rozprawa śliczna i podziwienia godna, Kraków. 


\section{On a Peculiarity in Judicial Oaths of Kalisz, which May Become a Warning for Researchers and Editors of Old Texts Summary}

The main purpose of the article is to show the problems that editors of Old Polish texts have to face. The pretext for showing these problems was a court note (card 67 recto), which was mistakenly published twice in the same edition (WRS - H. Kowalewicz and W. Kuraszkiewicz). Moreover, it was elaborated in two different ways (the same manuscript fragment is interpreted as the work of two different writers; the boundaries of the judicial record are indicated differently; the transcriptions of both versions also differ). Almost half a century later, all these errors were reproduced in the Electronic Repository of Greater Poland Oaths, although a dozen or so years earlier an edition by T. Jurek was published, in which the errors from the WRS edition were corrected. Unfortunately, the edition by T. Jurek also contains some solutions that make it impossible to use it in an entirely scientific manner (excessive modernization of the spelling). 